\title{
提言
}

\section{都市はいかにしてコンパクト化するのか？ 一立地適正化計画をめぐる論理と実態—}

How Can Cities Be Compacted? Logic and Reality of the Location Normalization Plan

\author{
武者 忠彦 \\ MUSHA Tadahiko
}

（2020年9月 28 日受付 2021 年1月 12 日受理）

本稿の目的は, 立地適正化計画によって都市はどのように変化し，それはコンパクト化として評価できるのかを 明らかにすることである，立地適正化計画は，コンパクトシティの拠点形成の仕組みとして制度化されたが，計画 を策定した都市のうち，大都市圈では，中心部における生活環境の充実などが課題に設定され，福祉や医療などの 生活関連機能を中心に都市機能が誘導されはじめている。一方, 地方都市の中心部では, 計画の課題や生活需要と は別の論理で，補助金を活用した公共施設の再編が進む傾向にある．今後，コンパクトシティを実質化するために は，立地適正化計画にもとづく都市機能の配置だけでなく，中心部における生活スタイルの波及や共有による居住 人口の増加が鍵となるだろう.

This study aimed to clarify how Japanese cities have changed under the Location Normalization Plan and whether the change can be evaluated as "compacting." The Location Normalization Plan was institutionalized as a framework to guide urban functions to the center of compact cities. In metropolitan areas where the plan has been implemented, the improvement of the city center living environment is an important issue, as urban functions such as welfare and medical care are being guided to relocate to city centers. On the other hand, public facilities are being guided and restructured in the centers of local cities. In the future, the key to acheiving compact cities will not only be the distribution of urban functions based on the Location Normalization Plan, but also the increase in the residential population through the sharing of lifestyles among local communities.

キーワード：コンパクトシティ，立地適正化計画，都市機能，誘導施設

Key words: compact city, Location Normalization Plan, urban function, guiding facility

\section{I はじめに}

コンパクトシテイという用語は, 日本では世紀の変 わり目から 20 年ほどの間に，あらゆる政策分野で用 いられるほどのキーコンセプトとなった。 とりわけ地 域の持続可能性を問われている地方都市の多くは，コ ンパクト化が都市政策上の最重要課題とされている. 都市の成長とその対応が一貫したテーマであった近代 日本の都市政策を振り返れば, これは大きな方向性の 転換であるが，その背景にある論理は，大きく次の 5 点に整理されるだろう。第 1 に，都市機能を集約して 不動産価值の維持や行政投資の効率化を進める行財政 の論理, 第 2 に, 教育・医療・福祉などの機能を集約 して子育て世帯や高齢者の生活環境を整えるという福 祉の論理, 第3に, 低炭素でエネルギー消費の少ない 都市にするという環境の論理，第 4 に，災害リスクの
低い地域に集住してレジリエンスを強化するという防 災の論理，そして第5に，市街地の既存ストックを活 用して都市の歴史や文化を継承する担い手を包摂する という文化の論理である。

こうした議論に対して，大都市圈のように生活サー ビスの個別化が進んだ地域では，コンパクトシティの 実効性が低いといった批判もなされているが（野澤 2014), コンパクト化という大きな方向性は官学で共 有されており，それを推進する制度として，2014年 8 月の都市再生特別措置法の改正によって創設されたの が，立地適正化計画（以下，立適計画）である，立適 計画は,「都市計画法を中心とした従来の土地利用の 計画に加えて, 居住機能や都市機能の誘導によりコン パクトシティ形成に向けた取組を推進」（国土交通省 都市局都市計画課 2018: 4）するための計画であり, 国土交通省が作成した『都市計画運用指針（以下，運 
用指針)』および『立地適正化計画作成の手引き（以 下，手引き)』にもとづいて，市町村が策定するもの である ${ }^{1)}$ 、『手引き』によれば，土地利用規制によっ て都市をコントロールする従来の都市計画と異なり， 財政支援や税制措置などの誘導によって都市をマネジ メントするための制度であるが，この立適計画によっ て都市はどのように変化するのだろうか. そして，そ れはコンパクト化としてどのように評価できるのだろ うか. これが本稿の基本的な問題意識である.

コンパクトシティや立適計画については，国内では 都市計画学を中心にこれまでも多くの研究が蓄積され ている.コンパクトシティ研究は，海道（2001）を嗃 矢として, 理論や海外事例の研究を中心に展開してき たが，コンパクトシティの目的や構造は，時代や政策 分野によって異なるという点が重要である（畠山 2017)。一方，立適計画については制度上の課題や問 題点を明らかにした研究を中心に展開してきたが（荒 木 2017; 浅野・河野 2019)，立適計画という制度を利 用したコンパクト化が，そもそも都市のいかなる課題 を解決しようとしたものであり，結果的に都市空間を どのように変容させたのかという各都市の運用面に光 を当てた研究，すなわち，制度よりも都市に重心を置 いた研究はまだ緒についたばかりである.

以上のような問題意識と先行研究の状況を踏まえ て，本稿では次の三つの論点を明らかにしていきた い. 第 1 に，立適計画が前提とするコンパクトシティ の論理はどのように形成され，その中で立適計画はど う位置づけられるのか. 日本のコンパクトシティをめ ぐる政策過程の全体像を把握し，立適計画がめざすコ ンパクト化の意味を明らかにする，第 2 に，それぞれ の都市が立適計画を用いたコンパクト化によっていか なる課題を解決しようとしているのか. 立適計画を策 定した都市の計画資料にもとづいて整理する。第3 に，立適計画はどのように都市機能を誘導し，それは 都市空間をどのように変えつつあるのか，筆者らが実 施した全国的なアンケート調査にもとづいて実態を明 らかにする，その上で，最後に立適計画をめぐる政策 を評価し，今後に向けた望ましい都市のコンパクト化 のあり方を提言したい.

\section{II コンパクトシティの論理}

コンパクトシティは, その概念が広まった 2000 年 代以降, 必ずしも一貫した政策体系によって推進され てきたわけではなく，分野や時期によって異なる論理 で政策に導入されてきた。 そのため，コンパクトシ ティに対して抱く目的や都市像については，本流の都 市政策だけでなく，関連する政策分野の動きを複線的 に考える必要がある，ここでは，主に国土交通省が所 管する都市政策分野のほか, 総務省や内閣府が所管す る地域政策分野，主に経済産業省が所管する産業政策 分野について，それぞれの政策テーマの変遷と相互の 関係を明らかにしながら，コンパクトシティをめぐる 論理を整理してみたい（図1）。

\section{1. 都市政策分野}

はじめに都市政策分野の動向からみていくと, コン パクトシティ論の原点は, 1997 年 6 月の都市計画中央 審議会基本政策部会中間とりまとめ「今後の都市政策 のあり方について」に見出すことができる（国土交通 省都市局都市計画課 2017)。このレポートでは，郊外 開発を抑制して既成市街地に都市機能を再配置する政 策に転換すべきという原初的な集約化の考え方が表明 された。その後，2003年12月の社会資本整備審議会 答申「都市再生ビジョン」において, 経済の成熟化や 人口減少に対応するためには，都市機能の集約化と集 約拠点での既存ストックの活用による「集約・修復保 存型都市構造」が必要であるとの考え方が示され，さ らに 2006 年 2 月の同審議会答申「新しい時代の都市計 画はいかにあるべきか.（第一次答申)」では，集約拠 点間を公共交通ネットワークで連携させて, 都市圈全 体で機能を分担する都市構造モデルが提示されたこと で, コンパクトシティの議論が深められていった。し かし，2009年6月に提出された同審議会都市計画部会 報告 ${ }^{2)}$ では, 都市圈の枠組は後退し，代わって都市内 の拠点をネットワーク化した「エコ・コンパクトシ テイ」という考え方が示された。 それは日常生活圈を イメージして「集約型都市構造化」を説いた 2012 年 9 月の同審議会都市計画制度小委員会中間とりまとめ ${ }^{3)}$ でも継承され，以後の都市政策分野におけるコンパク トシティの基調的な考え方となっている.このような 


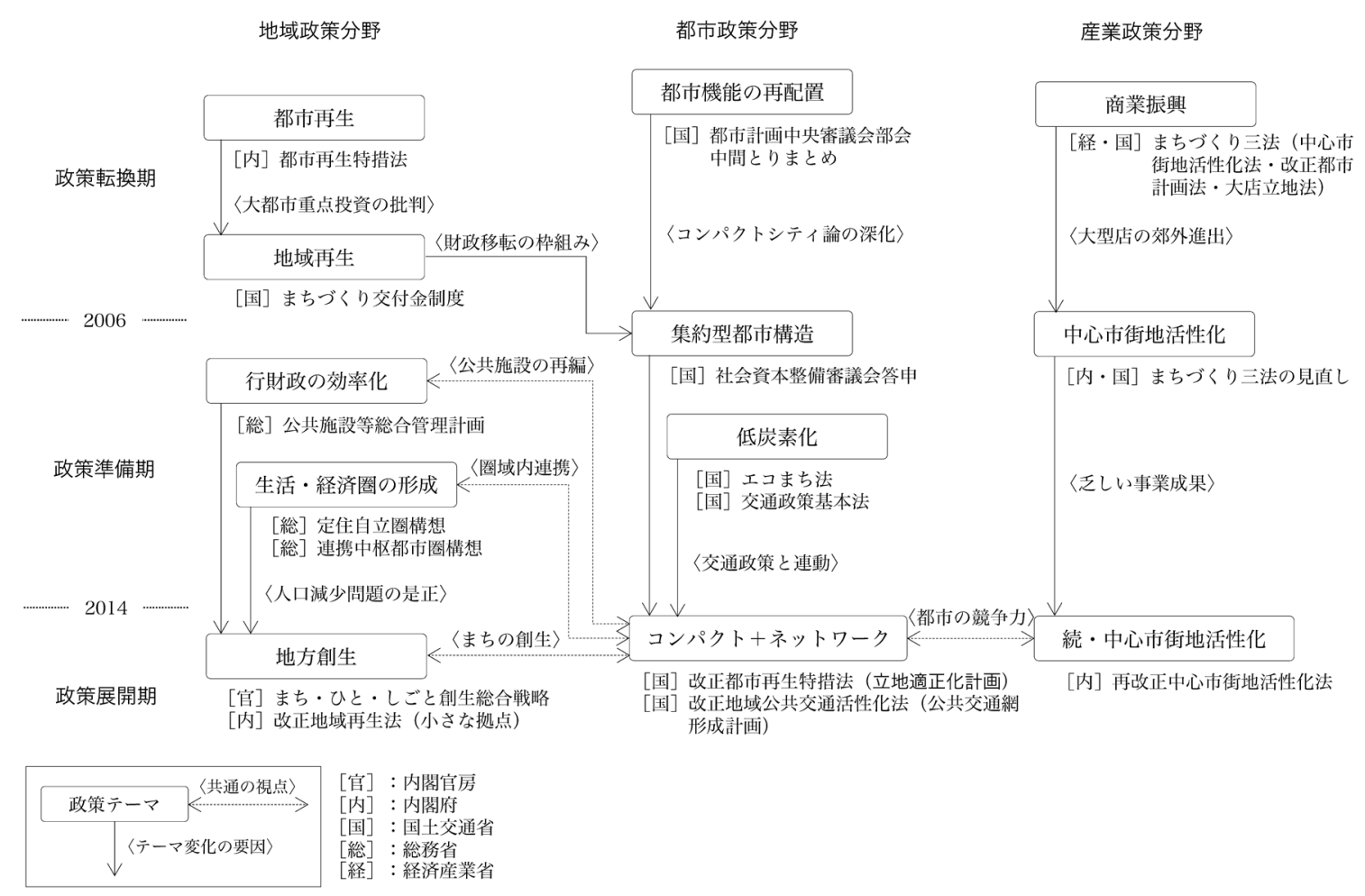

図1 コンパクトシティをめぐる政策過程

Fig. 1 Policy processes of compact cities

方向修正の背景には，2010年 3 月時点で約半数の市町 村都市計画マスタープランが都市のコンパクト化に言 及していたように4)，市町村単位での構想が進んでい たという現実もあったと考えられる。

こうした審議会での議論を受けて，国土交通省では 2013 年 4 月に都市再構築戦略検討委員会を設置し, 7 月には後の立適計画の原案を示した中間とりまとめを 作成している。ささら，2014年7月に公表された「国 土のグランドデザイン $2050 」$ 以降は,「コンパクト+ ネットワーク」というコンセプトを掲げて政策を推進 していった ${ }^{5)}$. この時点で「ネットワーク」が強調さ れた背景には次の 2 点が考えられる。第 1 に，平成の 大合併により周辺地域に旧市町村の中心部を抱えた都 市が多いという実態に即して，拠点間を結ぶネット ワークの重要性を示す必要があった。第2に，2012年 12 月施行のエコまち法や 2013 年 12 月施行の交通政策 基本法によって推進される都市の低炭素化，あるいは 2014 年 1 月公表の交通政策審議会地域公共交通部会中 間とりまとめ ${ }^{6)}$ で示された持続可能な公共交通ネット ワークという国土交通省の取組みにおいて，交通政策
と都市政策を連動させる必要があった。これらを背景 に生まれた「コンパクト+ネットワーク」というコン セプトを具体化する装置として，拠点形成を推進する 立適計画を制度化した改正都市再生特別措置法, 周辺 地域の「小さな拠点」の形成を支援する改正地域再生 法, さらに，それらの拠点間をつなぐための地域公共 交通網形成計画を制度化した改正地域公共交通活性化 再生法が2014年以降に相次いで施行された。

このように，都市政策分野においては人口減少時代 に合わせた都市構造への転換という視点からコンパク トシティの議論がはじまり，市町村単位で既存の都市 構造を生かしつつ集約化を進めるため, 交通政策とも 連動して「都市内多拠点型」のコンパクトシティが構 想されたといえるだろう。

\section{2. 地域政策分野}

コンパクトシティの政策的な起源を財政面からたど ると, 小泉政権下の「都市再生」政策まで遡ることが できる。2002年 6 月に施行された都市再生特別措置法 では，不動産の収益性や資産価值を高めて不良債権の 
処理を進めるため，開発規制の緩和や金融支援が可能 な都市再生緊急整備地域が全国で指定され，大都市へ の民間投資の誘導が図られた（武者 2011）。その一方 で，東京を中心とする大都市圈への重点投資を誘導す る政策には多くの批判も寄せられ，最終的に都市再生 は「稚内から石垣まで」をスローガンとした「地域再 生」に読み替えられた（上崎 2005）。これによって， 2004 年には市町村からの提案で市街地整備の予算を 配分するまちづくり交付金制度が創設されたが，こう した都市再生特別措置法による財政移転の枠組は，そ の後の都市機能の集約化の萌芽となった. すなわち, 経済戦略としての都市再生は大都市圈の都心部におけ る民間投資を誘導し，その見返りとしての地域再生 は，地方都市の市街地において行政主導の施設整備を 推し進めたのである。まちづくり交付金は，2010年 度からは都市再生整備計画事業に移行されたが，その 一部は事業名称を変えて継承され，2020年度には他 の事業と統合されて都市構造再編集中支援事業とな り, 地方都市のコンパクト化を推進する重要な財源と なっている ${ }^{7)}$.

このように，都市再生の系譜からコンパクト化が動 き出した一方で, 総務省が所管する分野においても, コンパクトシティとつながる行財政の効率化という政 策テーマが登場する。背景には，人口減少時代におけ る地方財政上の諸問題，すなわち住民税や固定資産税 からなる地方税収の低下, 扶助費やインフラ更新費用 の増加, そしてサービス単価の上昇があった（辻 2015)。これらの問題のうち, 住民税減少と扶助費増 加は避けられないが, それ以外は都市のコンパクト化 により回避できる問題であり，その一つが2000年代 以降の地方行財政改革で進められてきた公共施設の再 編である．具体的な動きとして，2010年前後より市 町村では公共施設の現状や課題を整理した公共施設白 書が作成され，2014年には，総務省の要請により各 市町村で公共施設等総合管理計画が策定された。これ に対して，2014年4月に国土交通省からは「まちづく りのための公的不動産 (PRE) 有効活用ガイドライ ン」が発表され，コンパクトシティを見据えた公的不 動産の再配置を指針化したように，公共施設の再編と コンパクトシティは表裏一体のテーマとして進められ た。
一方，人口減少への根本的な対応として，地域政策 分野では新しい自治構想によって都市のコンパクト化 を推進する動きもみられた。一つは，5万人程度の中 心市と周辺市町村で生活圈を構成して人口の流出を防 ぐ「ダム機能」を備えるため, 2009年から全国展開 した定住自立圈構想であり，もう一つは，政令指定都 市や中核市を中心市として周辺市町村が都市圈を構成 し，自立性の高い経済圈を形成することをめざした連 携中枢都市圈構想 ${ }^{8)}$ である. いずれも圈域内の各都市 の拠点をコンパクト化して人口密度を維持するととも に，行政単位を越えて拠点間をネットワーク化して圈 域内の連携を進め，圈域全体の人口を維持するという 構想である。2014年には，こうした地域政策テーマ や都市政策の「コンパクト+ネットワーク」の考え方 を統合して, 地方の人口減少問題の是正に総合的に取 り組む地方創生のスキームが動きはじめた。その指針 として毎年度策定される「まち・ひと・しごと創生総 合戦略」では，立適計画の策定数や連携中枢都市圈の 形成数を重要業績評価指標（KPI）とした「まち」の 創生が揭げられ，広域圈域から日常生活圈域まで, 多 様なスケールのまちづくりが志向されている ${ }^{9)}$ 。これ らの取組みに対して地方創生推進交付金による財政的 裏付けもなされたことで，コンパクトシティをめぐる 都市政策と地域政策の連携はさらに強まっている.

以上のように，地域政策分野では都市再生の系譜か ら地方都市のコンパクト化を下支えする財政移転の枠 組が形成され，地方創生を通じて都市政策との連動性 も高まっているが, 想定されている都市構造は, 行政 単位を越えてネットワーク化する「都市圈多拠点型」 のコンパクトシティであるといえる.

\section{3. 産業政策分野}

産業政策分野では, 1998 年から 2000 年にかけて中 心市街地活性化法（以下, 中活法), 改正都市計画法, 大規模小売店舗立地法の三つで構成される「まちづく り三法」が整備された。その主眼は1990年代の規制 緩和による大型店の出店攻勢に対して，既存の中心商 店街の求心力を維持することにあったが（箸本 2016）, 郊外では大型店の進出に歯止めがかからず, 中心市街地でも活性化を推進するはずのタウンマネジ メント機関（TMO）が十分に機能しなかった. 2004 
年 9 月には, 総務省の「中心市街地の活性化に関する 行政評価・監視結果に基づく勧告」において，中心市 街地活性化基本計画の事業効果が不十分であることが 指摘されている，さらに2005年 8 月には，国土交通省 が中心市街地活性化政策の評価などを行う目的で設置 したアドバイザリー会議の報告書 ${ }^{10)}$ が提出され，ま ちづくり三法の成果がそしい状況に対して, 拡散型都 市構造から集約型都市構造への転換の必要性が指摘さ れた。

こうした状況を受けて，まちづくり三法は「さまざ まな都市機能がコンパクトに集約した，歩いて暮らせ るまちづくり」をスローガンに大幅に見直されること になった。 とりわけ，2006年6月に改正された中活法 は，商業中心の支援から，市街地整備や居住，福祉の 分野に支援事業が拡大し，経済産業省以外に国土交通 省や総務省にも所管領域が及んだことで，新たに内閣 府の所管法令へと格上げされた。こうした変化は，中 活法の焦点が商業振興から多様な都市機能の集約によ る中心市街地活性化にシフトしたことを意味している が，基本計画に認定される中心市街地は原則として 1 市町村に1区域であったため，中心市街地活性化の枠 組で想定されていたのは，拠点が一つのコンパクトシ ティであったといえる.

2007年 2 月には，コンパクトシティの形成を揭げた 青森市と富山市の中心市街地活性化基本計画が改正中 活法の下で最初の認定を受け，その後2012年 3 月時点 までに119都市で138の基本計画が認定された。しか しながら，これは改正前の中活法下での認定数 606 と 比べて大きく減少する結果となり，各都市の基本計画 における目標指標も，販売額や空き店舗数を中心に多 くが未達成となった（中西 2014）。このような事業成 果のそしさによって，早くも中活法の再改正を含む中 心市街地活性化政策の見直しが検討されはじめた．経 済産業省では2013年 2 月に産業構造審議会中心市街地 活性化部会が設置され，商業振興の視点から中心市街 地活性化の方策が提言 ${ }^{11)}$ される一方，国土交通省で は4月に都市再構築戦略検討委員会が設置され，都市 構造の視点から集約化の戦略が示された。同年 6 月に 閣議決定した安倍政権の成長戦略「日本再興戦略」で は，こうした両省のねらいを併記した項目「コンパク トシティの実現」が立てられ，コンパクトシティは都
市の競争力の源泉に位置づけられた。これを受けて， 内閣官房は同年 7 月に中心市街地活性化推進委員会を 設置し，12月には報告書 ${ }^{12)}$ を取りまとめ，2014年7 月に中活法は再改正された。

このように，産業政策分野では当初のまちづくり三 法が商業の活性化につながらず，より本質的な対応と して中心市街地の構造転換を迫られてコンパクトシ ティの考え方が導入されたが，商店街の維持を出発点 としていた産業政策では，既成の中心市街地を拠点と する「単拠点型」のコンパクトシティが志向された.

\section{4. 立地適正化計画の位置づけ}

図1に示したように，2000年代前半に各分野で萌芽 的な動きがみられたコンパクトシテイ論の政策への導 入は， 2000 年代後半から制度化へ向けた議論や関連 する政策間の連携が進み，2014年以降は「コンパク ト+ネットワーク」を中心的な政策テーマとして，さ まざまな戦略や計画が展開している，その過程で, 単 純化を恐れずに言えば，都市政策分野では既存の都市 構造や交通政策との連動を背景にした「都市内多拠点 型」, 地域政策分野では生活圈や経済圈の維持を目的 とした「都市圈多拠点型」，産業政策分野では既成の 中心市街地を拠点とする「単拠点型」のコンパクトシ ティがそれぞれ構想された ${ }^{13)}$. このようなコンパクト シティ関連の政策体系において，立適計画は都市内多 拠点型コンパクトシティに抢ける拠点を形成するため の制度として機能することが期待されている. 従来, こうした拠点の形成・維持には, 都市計画法にもとづ く土地利用規制等で立地可能な機能の条件を一律に示 すという手法が用いられてきたが，立適計画はそれぞ れの都市が立地させたい機能を選択的に誘導するとい う「全く新しい仕組み」(国土交通省都市局都市計画 課 2018: 5）である.

財政面からも立適計画の重要性がみてとれる. 2020 年度のコンパクトシティ関連予算でみると, 経済産業 省の主要事業である商店街活性化・観光消費創出事業 の予算規模が約 50 億円であるのに対して，まちづく り交付金を起源とする国土交通省の都市構造再編集中 支援事業は約 700 億円となっている。この中には，市 街地再開発事業などの既存事業が拠点の区域内で実施 される場合の補助率の嵩上げや，公的不動産の活用等 
により都市機能を整備する民間事業者に対する補助事 業など，手厚い支援が含まれている（中井 2017）。こ うした支援措置も影響し，2020年 4 月時点で中心市街 地活性化基本計画に認定された都市が 150 であるのに 対して，7年遅れて制度化された立適計画の認定は 275 都市となっている。

\section{III＼cjkstart都市の課題とコンパクト化}

第2の論点は，都市内多拠点型のコンパクトシティ を形成しようとする立適計画を用いて，それぞれの都 市がいかなる課題を解決しようとしているのかという 点である。

立適計画は，おおむね次の九つのステップで構成さ れている。 まずは，1）関連する上位計画などとの関 係が整理され，2）各都市の課題が分析される．析出 された課題を踏まえて，3）ターゲットとよばれる立 適計画がめざすまちづくりの方針が示され，方針を実 現するための4）都市の骨格構造や5）ストーリーと よばれる施策・誘導方針が提示される。続いて，これ らの方針などに即して6）具体的に誘導する施設や区 域が設定され，7）誘導するための方策が示される. 最後に，8）活動のアウトプットやアウトカムを計測 する目標值，9）5年ごとに行われる評価の方法がま とめられるという構成である.

このうち，各都市の課題を端的に表明するのが
3）～5）に該当するステップであり，中でも計画全体 の方針を示すターゲットと，それを実現するための個 別の目標や方向性を体系的に整理したストーリーは, 各都市が認識する課題が最も反映されている。ただ し，ターゲットとストーリーの記載内容は都市によっ て抽象度が異なり，政策・施策・事業の各次元に相当 する内容が混在している。ここでは都市間の比較分析 を行うために，政策ほど抽象的でなく，事業ほど個別 具体的でない施策相当の内容に限定して, 計画で設定 された課題を明らかにする.

分析対象とした都市は, 2020 年 4 月 1 日時点で立適 計画を公表している275都市である。これらの都市の 立適計画にあるターゲットやストーリーから，表1に あげた $\mathrm{A} \sim \mathrm{K}$ の 11 分野の施策に相当する内容を抽出 して集計した ${ }^{14)}$ ．まず全体的な傾向をみると，「コン パクト +ネットワーク」のコンセプトを直接的に反映 している中心拠点への人口や機能の集約（A）と公共 交通ネットワークの再編（C）は，8割に及ぶ都市が 重点的な施策に掲げている。一方で，コンパクト化に ともなう移動量の抑制によって環境負荷を低減させる 低炭素型のまちづくり（K）を施策とする都市は，わ ずか $3 \%$ 程度にすぎない。その他の施策が選ばれる割 合は 10 ～40\%台であり，それぞれの都市のねらいに よって取捨選択されたものといえる。ここでは都市の 立地 ${ }^{15)}$ と規模による違いに着目しながら順に考えて みたい。

表 1 立地適正化計画における分野別の施策化割合（立地別・規模別）

Table 1 Percentage of cities adopting policies on compacting by location and size

\begin{tabular}{|c|c|c|c|c|c|c|}
\hline & \multirow[b]{2}{*}{ 施策 } & \multicolumn{2}{|c|}{ 立地 } & \multicolumn{2}{|c|}{ 規模 } & \multirow[b]{2}{*}{ 全体 } \\
\hline & & 大都市圈 & 地方圈 & 10 万以上 & 10 万以下 & \\
\hline A & 中心拠点への集約 & 80.9 & 80.1 & 81.1 & 79.7 & 80.4 \\
\hline B & 生活拠点への集約 & 28.7 & 35.9 & $\underline{42.6}$ & 26.1 & 33.5 \\
\hline $\mathrm{C}$ & 公共交通の再編 & 72.3 & $\underline{83.4}$ & 79.5 & 79.7 & 79.6 \\
\hline $\mathrm{D}$ & 地域経済の振興 & 29.8 & $\overline{29.3}$ & 32.8 & 26.8 & 29.5 \\
\hline $\mathrm{E}$ & 移住定住・空き家対策 & 33.0 & 27.6 & 21.3 & $\underline{35.9}$ & 29.5 \\
\hline $\mathrm{F}$ & 子育て環境の充実 & $\underline{48.9}$ & 33.1 & 32.8 & $\underline{43.1}$ & 38.5 \\
\hline G & 高齢者の生活環境整備 & $\overline{30.9}$ & 24.3 & 23.8 & $\overline{28.8}$ & 26.5 \\
\hline $\mathrm{H}$ & コミュニティの維持 & 12.8 & 18.8 & 18.9 & 15.0 & 16.7 \\
\hline I & 防災対策の強化 & 20.2 & 26.5 & $\underline{30.3}$ & 19.6 & 24.4 \\
\hline $\mathrm{J}$ & 財政の効率化 & 12.8 & 18.2 & $\overline{16.4}$ & 16.3 & 16.4 \\
\hline K & 環境負荷の低減 & 3.2 & 3.3 & 3.3 & 3.3 & 3.3 \\
\hline
\end{tabular}

注：一方の属性より $10 \%$ 以上高い数值は下線で強調した.

(各都市の立地適正化計画より筆者作成) 
立適計画では生活拠点などに位置づけられる合併前 の周辺市町村の中心部や集落への人口や機能の集約 （B）は，中心拠点に比べれば重要視されていない. それでも, 地方圈の規模の大きな都市で数值が高く なっているように, 新潟市や長野市, 東広島市など, 中心市が広域の市町村を編入して合併した都市などで は, 周辺部の拠点性も依然として重要視されている. 多くの都市が掲げる公共交通ネットワークの再編 （C）については，都市規模による違いはないが，す でに鉄道やバスのネットワークが充実して再編の必要 性が低い大都市圈と, 公共交通の維持が喫緊の課題と なっている地方圈との差異は大きい. $\mathrm{U} \cdot \mathrm{I} ・ \mathrm{~J}$ ターン による移住・定住の促進と中心部に増えている空き家 の利活用を進めようとする施策（E）は，今後急速な 人口減少が見达まれる小規模の都市で割合が高くなっ ている.もっとも, これは地方圈に固有の課題ではな く, 埼玉県西部や奈良県など, 大都市圈縁辺部に位置 する都市でも頻出の施策となっている．同じような文 脈で，中心部における子育て環境の充実（F）も人口 減少対策として重要な課題であり, 移住定住・空き家 対策を掲げる都市のうち半数は, 子育て環境も合わせ て施策化している，子育て環境の充実はまた，高齢者 の生活環境の充実 $(\mathrm{G})$ と並んで, 中心拠点周辺の再 開発が進む大都市圈の都市でもニーズが高い施策であ る。たとえば，関西大都市圈の豊中市，吹田市，茨木 市，高槻市など，鉄道沿線の人口稠密な都市では，子 育て世代や高齢世代の支援施設を鉄道駅周辺に集約す る動きがみられる，分散している都市基盤を集約し て，地震や津波，大雨などの災害に対するレジリエン スを強化しょうとする施策（I）は，沼津市や高知市 など，南海トラフ地震などの災害リスクが高いとされ る地域にある都市のほか, 多様な施策を総合的に展開 することが可能な規模の都市において施策化されてい ることがうかがえる．公共施設の再配置や都市基盤の 集約など，コンパクト化にともなう財政の効率化 $(\mathrm{J})$ は，財政が逼迫している地方圈の都市でやや多い傾向 がみられた。

以上のような分野別の施策の集計におけるもう一つ の興味深い結果は，近隣の都市間で傾向が類似する ケースが散見されたことである. ターゲットの内容が ほぼ同一の北広島市と福島町は極端な例としても, 秋
田県や茨城県, 神奈川県, 愛知県などでは, 県内のい くつかの都市で構成や施策の組合せの類似性が高い. もちろん，いくつかのケースでは計画策定業務を受託 する業者が同一であるという背景もあるだろうが，こ こから導かれるより重要な背景は, 計画策定過程にお ける各都市の主体性の欠如である．伊藤（2002）は, これを政策立案過程における自治体の「相互参照」行 動としているが，こうした相互参照の結果として， 「歩いて暮らせる」「持続可能な」「安心・安全で便利 な」都市などのように，どの都市でも入れ替え可能な 内容のターゲットと，それに紐づけられた総花的なス トーリーが展開される傾向がある.

以上のように，立適計画で設定された課題を分析す ると，立適計画を利用してコンパクトシティの拠点を 形成することで，周辺部の拠点性に配慮したい広域合 併都市，公共交通を維持したい地方都市，移住・定住 と空き家活用を推進したい小規模都市や大都市圈縁辺 部の都市, 駅周辺の生活環境を充実させたい大都市圈 中心部の都市, レジリエンスを強化したい災害リスク の高い都市など，都市の立地や規模によって設定され る課題には一定の傾向がみられた。ももとも，こうし た課題設定の傾向は, 各都市の主体的な選択の結果と いうよりも，都市間の相互参照の可能性が指摘できる ように，都市の立地や規模にしたがって受動的に選択 された結果とも考えられる。

\section{IV＼cjkstart誘導施設からみたコンパクト化}

第3の論点は, 以上のような課題に対して立適計画 はどのように都市機能を誘導し，それは都市空間をど のように変えつつあるのかという点である.

各都市の立適計画では, ターゲットやストーリーに 即して，医療・福祉・商業などの施設を誘導する「都 市機能誘導区域」と, 住宅を誘導して密度を維持する 「居住誘導区域」が設定される。この居住誘導区域が 都市計画法における既存の市街化区域の一部に設定さ れ，さらに都市機能誘導区域が居住誘導区域の一部に 設定されることで，従来よりもコンパクトな都市が形 成されるという制度設計になっている ${ }^{16)}$ 。これらの誘 導区域内の施設や住宅を維持したり，誘導区域外から の移転を促すために，事業に対する国庫補助率の嵩上 
げ，民間開発事業者に対する金融支援や規制緩和，関 連する都市基盤の整備などのインセンティブを与える 一方で, 区域外の建築・開発行為を届出・勧告によっ て抑制することで，緩やかに立地誘導を図る仕組みで ある。

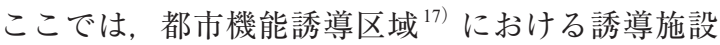
の立地動向に着目して，コンパクト化の実態を明らか にしたい. 誘導施設とは, 都市機能誘導区域に立地誘 導すべき都市機能を備えた施設のことで，『手引き』 によれば，行政，介護福祉，子育て，商業，医療，金 融，教育・文化の7種類の機能が例示されている．立 適計画では，これらの誘導施設がもつ都市機能によっ て居住人口が引きつけられる「マグネット効果」を想 定していることから（浅野・河野 2019），誘導施設の 立地動向は, 各都市のコンパクト化へ向けた取組みの 先行指標といえる.

筆者らは，2018年 12 月末時点で立適計画について 具体的な取組みを行っている440市町村（国土交通省 発表）に対して，2019年2月にアンケート調査「立地 適正化計画への取組みと関連するまちづくり政策に関 する調査」を実施し，332市町村から有効回答を得た (回答率 75.5\%)。この中で，すでに事業が完了した施 設から事業計画公表済みの施設まで，施設が固有名で 特定可能な誘導施設について，機能や誘導の経緯，建 築手法，土地所有形態，誘導に用いた施策などを質問 した。なお，誘導施設は小規模な食品スーパーや診療 所などを含めると相当な数となるが, 本調査では, 当 該市町村全域を対象としたサービスを提供する「中心
拠点」レベルの機能（施設）と，一部の地域にサービ スを提供する「生活拠点 $\rfloor^{18)}$ レベルの機能（施設）に 区分した『手引き』の例示にしたがって，中心拠点レ ベルの誘導施設（以下，中心拠点施設）に調查対象を 限定している.

集計の結果, 332 市町村のうち, ほぼ3分の 1 にあ たる112市町が中心拠点施設の誘導を計画または実施 し，施設数は延べ 223 施設であった ${ }^{19)}$ 。もちろん，制 度施行から 5 年ほどの実績であり，今後施設数は増え ていくはずであるが，誘導を方向づける初動期の特徵 を把握するには十分な数であると思われる。ここで注 意すべきは，施設数と建物数は一致しない点と，誘導 の前後で施設数が異なる点である。これは誘導にとも なって，ホールと図書館を一つの建物に合築するよう な場合や，役所の本庁舎へ支所を統合するようなケー スがあるためである。ここでは，一つの建物に複数の 施設が合築される（同じ建物の内部で独立して存続す る）前者のパターンを「複合化」，複数の施設が一つ の施設に統合される後者のパターンを「統合化」と定 義する．実際の誘導は，こうした複合化や統合化のパ ターンを孕みながら，施設が建替えられたり，新たに 立地したり，移転したりすることによって進められ る，そこでまずは，複合化と統合化のパターンを整理 しておきたい.

リストアップされた 223 施設のうち，100施設は複 合化や統合化に該当しない単独の建替えや移転などで あるが, 残りの123施設は, 複合化または統合化をと もなう誘導施設となっている（表2）。このうち，複

表2 都市機能の複合化と統合化

Table 2 Complexity and integration of urban functions

\begin{tabular}{|c|c|c|c|c|c|}
\hline \multicolumn{3}{|r|}{ パターン } & 建物数 & 中心拠点 & 代表的な事例 \\
\hline 複合化 & $\begin{array}{c}\text { I } \\
\text { II } \\
\text { I + II } \\
\text { III } \\
\text { IV }\end{array}$ & $\begin{array}{l}\text { 中心拠点施設の合築 } \\
\text { 中心拠点施設への生活拠点施設の合築 } \\
\text { 中心拠点施設および生活拠点施設の合築 } \\
\text { 生活拠点施設の合築による中心拠点施設化 } \\
\text { 複合施設への入居 }\end{array}$ & $\begin{array}{r}14 \\
23 \\
10 \\
14 \\
6\end{array}$ & $\begin{array}{r}36 \\
23 \\
20 \\
14 \\
6\end{array}$ & $\begin{array}{l}\text { 図書館と公民館を合築した交流拠点施設 } \\
\text { 地域包括支援センターを内部化した市役所 } \\
\text { 子育て支援施設などを合築した交流拠点施設 } \\
\text { 保健所や診療所を一体化した保健センター } \\
\text { 商業施設に入居したサテライトキャンパス }\end{array}$ \\
\hline 統合化 & $\begin{array}{l}\text { I } \\
\text { II }\end{array}$ & $\begin{array}{l}\text { 中心拠点施設の統合（連携含む） } \\
\text { 中心拠点施設への生活拠点施設の統合 }\end{array}$ & $\begin{array}{r}7 \\
11\end{array}$ & $\begin{array}{l}13 \\
11\end{array}$ & $\begin{array}{l}\text { 病院の統合や地域医療連携推進法人の設立 } \\
\text { 市役所本庁舎への支所の統合 }\end{array}$ \\
\hline 単独 & & & 100 & 100 & \\
\hline 総計 & & & 185 & 223 & \\
\hline
\end{tabular}

（アンケート調査により筆者作成） 
合化には五つのパターンがみられた．特に地方圈の都 市では，図書館や基幹公民館などの中心拠点施設を核 として一つの建物に複数の施設が入居する複合化 $\mathrm{I}$, II, I + II のパターンの割合が大きい. 典型的な事例と して，富山市立図書館，富山市ガラス美術館，富山第 一銀行本店などで構成される富山市の「TOYAMA キ ラリ」などがある。これに対して大都市圈の都市で は，子育て支援施設などいくつかの生活拠点施設が複 合して中心拠点施設となる複合化III, IVのパターン が多い. 愛知県春日井市や刈谷市の駅前再開発事業で は，高層マンションに商業機能や福祉機能を組み込ん だ複合施設が開発されている。これに対して，統合化 のパターンはシンプルであり, 統合化 Iは病院間の統 合や地域医療連携推進法人の設立, 統合化 II は役所 · 役場の本庁舎への分庁舎や支所の統合にほぼ限定され る.

こうした複合化と統合化をともなって都市機能の誘 導がどのように進められたのか, 差異が明瞭な大都市 圈と地方圈を対比しながら，具体的にみていきたい. まず，機能については施設数の偏りを考慮して，『手 引き』の7類型から図2に示した6類型に再編した. 施設数の多い順にみていくと，基幹図書館や博物館な どの教育機能，大規模ホールや基幹公民館などの文化 機能の上位二つで誘導施設の半数以上を占める. 続い て, 役所・役場の本庁舎などの行政機能, 二次医療機 関や保健センターなどの医療機能, 福祉センターや子 育て支援施設などの福祉機能, ショッピングモールや ホテルなどの商業機能の順となる。 大都市圏では, 都 市中心部における子育て世帯の増加などを背景に, 商 業施設や子育て世代を包括的に支援する施設など，商
業機能や福祉機能の新規立地が増えているほか, 規模 の大きな病院が誘導区域内で移転したり統合されたり するケースが多いことも特徵的である。こうした傾向 は，大都市圈において子育て世代や高齢世代の生活環 境の整備が課題として重視されているというIIIの結 果とも平入が合う。一方，地方圈では先述の図書館や 公民館の複合化など，教育機能と文化機能の誘導が多 くなっている。こうした傾向もまた，地方圈において 公共施設の再編による行財政の効率化施策が大都市圈 よりも重視されているという前章の結果と符号する が，施策化の割合自体は低いため，行政課題として認 識されている以上に公共施設の再編が進んでいるとい える．地方圈において，全誘導施設のうち $49 \%$ が補 助金の獲得を誘導施策にしているというデータや，居 住誘導が事実上後回しになっている実状と重ね合わせ れば，地方圈では行政課題や生活需要とは別の文脈 で，補助金に依存したハコモノ整備中心のまちづくり が依然として駆動していると考えることもできる.

次に, これらの中心拠点施設について，どのように 誘導されたのかを明らかにするために，誘導類型別に 集計したものが表3である。ここでは，同じ場所で建 替えや増改築をした施設を「既存立地」，同じ誘導区 域内から移転した施設を「域内移転」, 誘導区域外か ら移転した施設を「域外移転」，誘導によって新設さ れた施設を「新規立地」に区分した．表3によれば, 一般的なコンパクト化のイメージである誘導区域外か らの移転は，全体の 1 割程度にすぎないことがわか る. 特に, 地方圈では既存立地と区域内からの移転の 施設で 4 分の 3 を占めているため, 都市構造が硬直的 で，大都市圈よりもコンパクト化が進んでいないよう

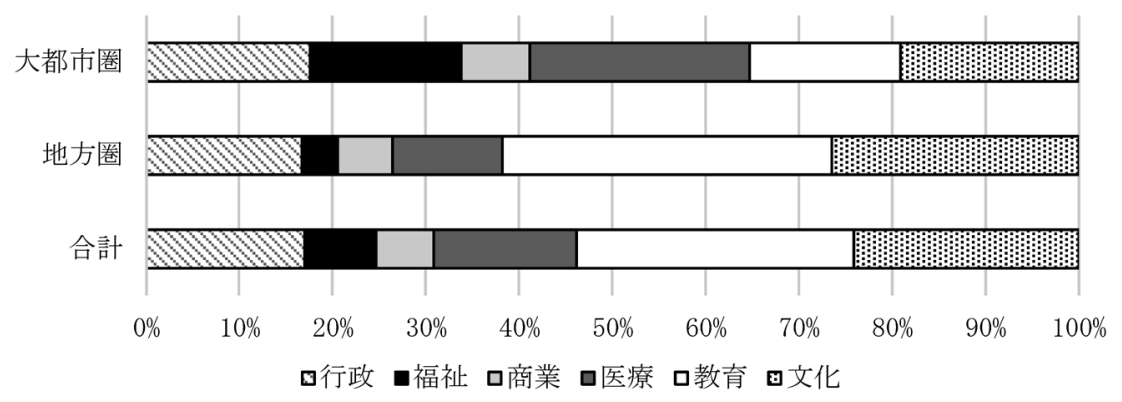

図2 都市機能別中心拠点施設の割合（地域別）

Fig. 2 Urban core facilities by function and region （アンケート調査により筆者作成） 
表3 誘導類型別中心拠点施設の割合（地域別）

Table 3 Percentage of urban core facilities by guidance type and region

\begin{tabular}{|c|c|c|c|c|c|c|c|c|c|c|}
\hline & \multicolumn{2}{|c|}{ 既存立地 } & \multicolumn{2}{|c|}{ 域内移転 } & \multicolumn{2}{|c|}{ 域外移転 } & \multicolumn{2}{|c|}{ 新規立地 } & \multicolumn{2}{|c|}{ 計 } \\
\hline 大都市圈 & 11 & $16.2 \%$ & 28 & $41.2 \%$ & 9 & $13.2 \%$ & 20 & $29.4 \%$ & 68 & $100.0 \%$ \\
\hline 地方圈 & 45 & $29.0 \%$ & 64 & $41.3 \%$ & 18 & $11.6 \%$ & 28 & $18.1 \%$ & 155 & $100.0 \%$ \\
\hline 計 & 54 & $24.2 \%$ & 89 & $39.9 \%$ & 27 & $12.1 \%$ & 41 & $18.4 \%$ & 223 & $100.0 \%$ \\
\hline
\end{tabular}

（アンケート調査により筆者作成）

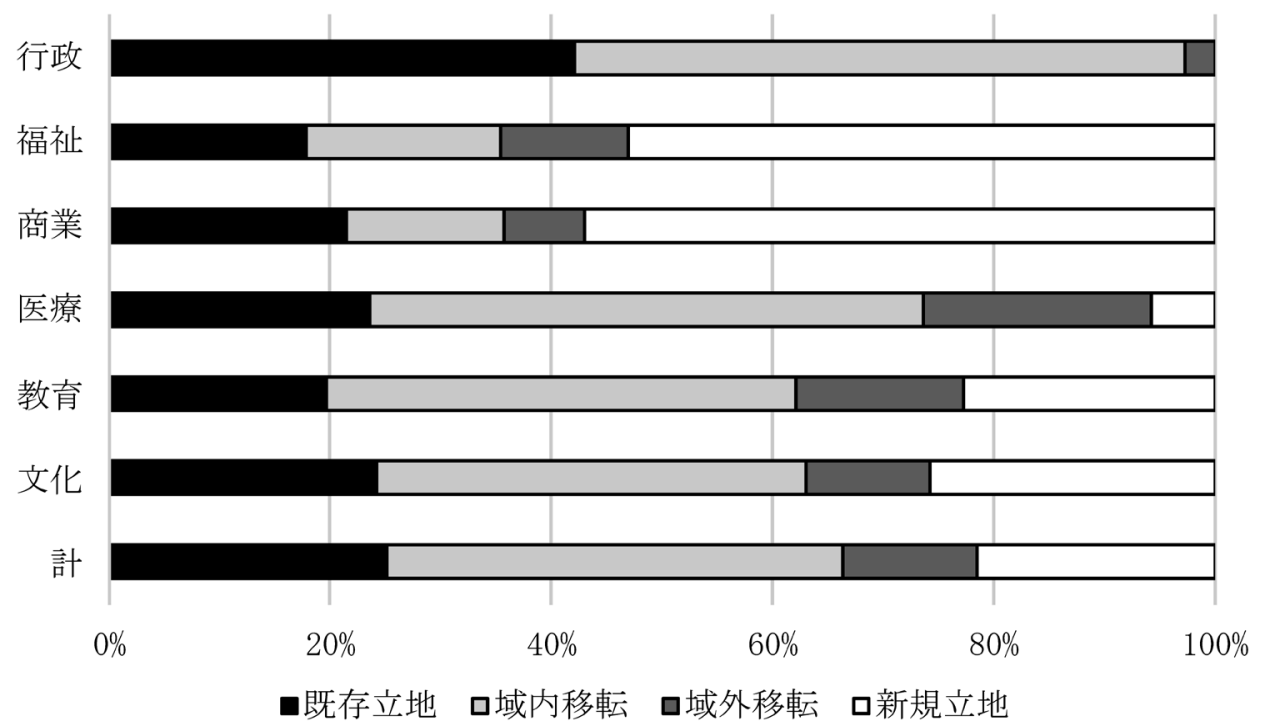

図 3 誘導類型別中心拠点施設の割合（都市機能別）

Fig. 3 Percentage of urban core facilities by guidance type and urban function (アンケート調查により筆者作成)

にみえる。この点に関して，施設の機能別に誘導形態 をみたものが図3である。 これによると，福祉機能と 商業機能で特に区域外からの移転や新規立地の施設が 多くなっているが, 大都市圈ではこれらの機能の割合 が地方圏よりも大きいことが流動性を高める一つの要 因となっている，もっとも，地方圈の既存立地や区域 内移転の施設であっても，複合化IIや統合化IIのパ ターンにおいて合築した生活拠点施設は区域外から誘 導しているケースもあるため，これらがコンパクト化 に全く寄与していないわけではない.

最後に，中心市街地における既存ストックの活用と いう観点から, 誘導施設の増改築と公有地活用の割合 について表 4 によめた。増改築は既存の建築物の活 用を意味しているが，その割合は，耐震基準などの問 題もあり全体の 1 割程度にとどまっている. 閉店した 大規模商業施設を改修して移転した土浦市役所本庁舎
表4 中心拠点施設の増改築および公有地活用の割 合 (都市機能別)

Table 4 Percentage of renovated urban core facilities and utilization of public land by urban function

(単位：\%)

\begin{tabular}{ccc}
\hline 都市機能 & 増改築 & 公有地活用 \\
\hline 行政 & 15.8 & 89.5 \\
福祉 & 23.5 & 76.5 \\
商業 & 7.1 & 23.1 \\
医療 & 5.9 & 59.4 \\
教育 & 12.1 & 70.3 \\
文化 & 3.7 & 79.6 \\
\hline 計 & 10.3 & 72.0 \\
\hline
\end{tabular}

（アンケート調査により筆者作成）

や，小城市の公民館を改築して新設された西九州大学 看護学部などの興味深い事例も含まれるが, 多くは福 祉機能や行政機能を中心とした公共施設の建て増しや 改修となっている。一方，建物だけでなく土地も含め 
たストックの活用という意味では, 新築の誘導施設も 有効活用に該当する. 特に，公共施設の跡地などの公 有地を活用する例は多く, 現地建替えも含めて, 全体 の $72 \%$ の誘導施設がそれまで公有地であった土地に 立地している ${ }^{20)}$. このように，公共施設や公有地を含 めた公的不動産の活用は，中心拠点施設を誘導するに あたって重要な手段となっている.

ここまで, 都市のコンパクト化の「マグネット」と なるはずの中心拠点施設の誘導状況をみてきた．大都 市圈では，都市機能誘導区域とその周辺において，一 定の居住人口にもとづく行政課題や生活需要がすでに 存在する。 そのため, 誘導区域内外から医療機能や福 祉機能を中心にさまざまな都市機能の施設が比較的バ ランスよく誘導されはじめている。 これに対して, 地 方圈では行政課題や生活需要とは別の文脈で, 公共施 設の再編が目的化していることで, 誘導区域内の公共 施設を複合化・統合化して新築する傾向が強いといえ る.

\section{V 望ましい都市のコンパクト化に向けて 一立地適正化計画の可能性と限界一}

立適計画によって都市はどのように変化するのか. それはコンパクト化として評価できるのか.これが本 稿の基本的な問題意識であった. 日本では, コンパク トシティをめぐる政策過程で「都市内多拠点型」「都 市圈多拠点型」「単拠点型」のコンパクトシティが構 想されたが，その中で立適計画は，都市内多拠点型コ ンパクトシティの拠点を形成するための制度として位 置づけられている，実際に立適計画を策定した都市で は，拠点を形成することで生活環境を充実させたい大 都市圈の都市や人口を維持したい地方都市など，それ ぞれの都市の立地や規模によって設定する課題にも一 定の傾向がみられた。こうした課題を踏まえて，大都 市圈の都市では福祉や医療などの生活関連機能を中心 に都市機能が誘導されはじめている一方で，地方圈の 都市では行政課題や生活需要とは別の文脈で，公共施 設の複合化や統合化が進められている.

こうした中心拠点施設の誘導によって都市のコンパ クト化が進展すればよいが, 都市機能の立地によって 期待される居住人口のマグネット効果が既存研究でも
明らかにされていないという事実（中井 2017）は, 行政主導で都市機能を先行して集約する手法による都 市のコンパクト化には限界があることを示唆してい る.これに対して, 中井（2017）や浅野（2019）など の先行研究は，立適計画において目標とされる人口密 度などの数值や計画の理念から，具体的な都市像や生 活スタイルをイメージすることの必要性を指摘する. 確かに，都市機能を配置するだけではなく，中心拠点 における都市像や生活スタイルが提示され，それに対 するニーズが生まれない限り，居住人口の増加は望め ないだろう。しかし，立適計画をめぐる目標值や理念 から，計画する側が望ましい都市像や生活スタイルを 予め導出することは困難であると同時に，必ずしも妥 当ではないように思われる。

急速な経済成長を背景に将来都市像を社会全体で共 有していた時代に対して，都市における生活ニーズが 充足された現代は，行政や大手資本などの計画主体側 が提起する「大きな社会的合意」としての将来都市像 が共有しづらくなり，多様な価值観や利害関係をもつ 市民のまちづくりプロセスへの参加が要請される時代 である（武者 2020）。実際に，昨今の中心市街地で は，行政主導の計画にもとづいて多額の補助金や民間 資金が投入された事業の多くが，ほとんど成果をあげ られない一方で，民間の個人間や企業間の「小さな社 会的合意」としてのローカルなデザインやリノベー ションの展開が，都市を変容させた事例が増えている (武者 2019)。これらの事例において, 将来都市像は 行政計画によって事前に共有されていたというより も，少数ないしは狭い範囲での実践から次第に波及し ていくプロセスをたどっている．都市のコンパクト化 についても，計画の合理性や予測可能性には限界があ ることを認識した上で，立適計画のような行政計画に もとづく都市機能の誘導と合わせて，ボトムアップに よる生活スタイルの醸成や既存ストックの利活用など があって，はじめてマグネット効果が生じることを認 識すべきである。このようなパラダイムの変化は，一 般法則にもとづいて中長期的な視点から都市を計画す る従来の工学的アプローチに加えて，ローカルな文脈 と多様な人間像を前提に都市の動態を理解する人文学 的アプローチが重要になること，すなわち，都市計画 やまちづくりがもはや「理系」の研究対象にとどまら 
ないことを意味しているといえるだろう．

\section{付 記}

本調查は, JSPS 科学研究費基盤(B)「地方都市再生 に向けた事業用ストックの利活用プラットフォームに 関する地理学的研究」(研究代表者: 箸本健二, 課題 番号：16H03526）の一部を使用した。

\section{注}

1）以下で用いるのは, 『第10版 都市計画運用指針』 （2018年9月改訂）および『立地適正化計画作成 の手引き』（2018年4月25日改訂）である.

2）国土交通省社会資本整備審議会都市計画・歴史的 風土分科会都市計画部会「都市政策の基本的な課 題と方向検討小委員会報告」.

3）国土交通省社会資本整備審議会都市計画・歴史的 風土分科会都市計画部会都市計画制度小委員会中 間とりまとめ「都市計面に関する諸制度の今後の 展開について」.

4）国土交通省資料「まちづくりの観点〜都市と交 通〜」（2011年11月）による.

5）それ以前にも，「多極ネットワーク型コンパクト シティ」という用語が各種文書で使われていた が，ネットワークがコンパクトシティと並列する かたちで強調されるようになったのは,「新たな 『国土のグランドデザイン』構築に関する有識者 懇談会」第 1 回会合（2013年10月）の配布資料 「新たな『国土のグランドデザイン』の構築につ いて」(国土政策局）からである。な扮，グラン ドデザインそのものは，人口 10 万人以上の中心 都市から 1 時間以内の交通圈にある人口 30 万人以 上の都市圈で必要な都市機能を維持することが想 定されているため, ネットワークも主に都市圈ス ケールのものが想定されている.

6）国土交通省交通政策審議会地域公共交通部会中間 とりまとめ「地域公共交通の充実に向けた新たな 制度的枠組に関する基本的な考え方」.

7）まちづくり交付金制度は，2010年度からは都市 再生整備計画事業に変更されたが，その一部が 2012年度補正予算から地方都市リノベーション 事業, 2014年度からは都市再構築戦略事業とし
て継承され，2020年度には都市機能立地支援事 業などと統合されて都市構造再編集中支援事業と なっている.

8）政令指定都市と中核市のうち，昼夜間人口比率 1 以上の都市（全国で61市）を対象に，近隣市町 村と「連携協約」を結んだ都市を連携中枢都市と して指定し, 圈域人口などに応じて普通交付税お よび特別交付税が措置される.

9）現状では群馬県館林都市圈を除いてすべて市町村 単位で策定されている立適計画も, 広域の生活圈 と経済圈が形成されている場合は，定住自立圈や 連携中枢都市圈を踏まえて計画を作成すべきとい う方針が『運用指針』と『手引き』に示されてい るように，地域政策における圈域連携の枠組を取 り入れる可能性はある（片山 2018）。

10）国土交通省「中心市街地再生のためのまちづくり のあり方に関する研究」アドバイザリー会議報告 書「中心市街地再生のためのまちづくりのあり方 について」.

11）経済産業省産業構造審議会中心市街地活性化部会 「中心市街地の再活性化に向けて（提言）」.

12）内閣官房地域活性化統合事務局中心市街地活性化 推進委員会「中心市街地活性化に向けた制度 · 運用の方向性」.

13）これら三つのコンパクトシティの型は, 必ずしも 排他的な関係にはないが，たとえば中心市街地活 性化基本計画と立適計画のいずれも策定している 都市では，目指すべき都市構造や設定された中心 拠点の範囲に矛盾も生じている(浅野・河野 2019).

14）275都市の立適計画に打けるターゲットおよびス トーリーに該当する部分について，表1にあげた $\mathrm{A} \sim \mathrm{K}$ の各分野に関連する内容の記載が一つで もあれば「施策化あり」とした，複数の分野に該 当すると思われる施策は重複してカウントせず に，いずれか一つの分野に分類した。

15）国勢調查における大都市圈の定義（中心市への通 勤・通学比率が $1.5 \%$ 以上の周辺自治体で構成さ れる圈域）にもとづいて，2015年における「関 東大都市圈」「中京大都市圈」「近畿大都市圈」を 大都市圈，それ以外を地方圈とした。 
16） 2017 年 7 月時点の全国平均で，市街化区域面積に 対して，居住誘導区域は $70 \%$, 都市機能誘導区域 は30\%となっている（宮崎ほか 2019）。

17）『運用方針』によれば，都市機能誘導区域は「鉄 道駅に近い業務, 商業などが集積する地域等, 都 市機能が一定程度充実している区域や，周辺から の公共交通によるアクセスの利便性が高い区域 等，都市の拠点となるべき区域」であり，その規 模は「一定程度の都市機能が充実している範囲 で，かつ，徒歩や自転車等によりそれらの間が容 易に移動できる範囲」である（国土交通省 2018).

18）国土交通省は中心拠点に対して周辺に位置する拠 点を地域拠点または生活拠点としているが, 本稿 では簡便のため生活拠点に統一する.

19）実際の回答では延べ355施設があげられたが，こ のうち, 生活拠点と思われる施設, 誘導する地点 が未定の施設は除外した。 また，維持すべき既存 の施設も本来は誘導施設に含まれるが，既存施設 について回答した市町村は一部に限られていたた め, このパターンの施設についても集計から除外 している.

20）公有地と民有地で構成されている土地も含めた値 である。

\section{文献}

浅野純一郎 2019。都市の縮退に向けた土地利用制度 の課題一一立地適正化計画を中心に. 地域問題研究 98: 3-8.

浅野純一郎・河野壱玫 2019. 地方都市における中心 市街地と都市機能誘導区域指定の関係に関する研 究. 都市計画論文集 54: 524-531.

荒木俊之 2017. 地理的な視点からとらえた立地適正 化計画に関する問題——コンパクトシティ実現のた めの都市計画制度. E-journal GEO 12: 1-11.

伊藤修一郎 2002.『自治体政策過程の動態——政策イ
ノベーションと波及』慶應義塾大学出版会.

上崎 哉 2005. 小泉政権による都市再生政策の理念 と方針と方向性について. 近畿大学法学 52(3・4): 33-83.

海道清信 2001.『コンパクトシティ—持続可能な社 会の都市像を求めて』学芸出版社.

片山健介 2018. コンパクトシティ政策と広域連携施 策の連携に関する基礎的分析一一都市機能の連携 · 分担に着目して.都市計画報告集 17: 58-63.

国土交通省都市局都市計画課 2017. コンパクトシ ティの本格的推進. 日本不動産学会誌 31(2): 37-43.

国土交通省 2018。『第10版都市計画運用指針』.

国土交通省都市局都市計画課 2018。 『立地適正化計画 作成の手引き（2018年4月25日改定版)』.

辻 环也 2015. 連携中枢都市圈構想の機制と課題 一超高齢・人口減少社会のまちづくりを誘導する 新しい地方行財政制度. 日本不動産学会誌 29(2): 49-55.

中井検裕 2017. 立地適正化計画制度のこれまでとこ れから.日本不動産学会誌 31(2): 31-36.

中西信介 2014. 中心市街地活性化政策の経緯と今後 の課題一一心市街地の活性化に関する法律の一部 を改正する法律案. 立法と調査 351: 97-111.

野澤千絵 2014. コンパクトシティは暮らしやすいま ちになりますか? 蓑原敬・饗庭伸・姥浦道 生・中島直人 · 野澤千絵 $\cdot$ 日埜直彦 · 藤村龍至 - 村 上暁信『白熱講義 これからの日本に都市計画は必 要ですか』156-172. 学芸出版社。

箸本健二 2016. 地方都市における中心市街地空洞化 と低利用不動産問題. 経済地理学年報 62: 121-129.

畠山 直 2017. 立地適正化計画制度における地域商 業の位置づけに関する考察——わが国のコンパクト シティ政策の変遷をとおして，熊本学園商学論集 21(1): 67-96.

宮崎慎也・鵤 心治・小林剛士・宋 俊煥 2019. 立 地適正化計画策定都市の誘導区域と誘導施策に関す る研究. 日本建築学会技術報告集 25(60): 881-886.

武者忠彦 2011.「都市再生」をめぐる都市ガバナン ス. 経済地理学年報 54: 307-319.

武者忠彦 2019. リノベーションによる地方都市の再 生一一長野市中心市街地における「地方の創造都市 化」と「都市の文脈化」. 統計 70(8): 33-38.

武者忠彦 2020. 人文学的アーバニズムとしての中心 市街地再生. 経済地理学年報 66: 337-351.

\section{〈著者略歴〉}

武者忠彦（むしゃ ただひこ）

1975 年長野県生まれ。信州大学学術研究院社会科学系教授. 博士 (学術). 専門は都市地理学および都市政策. 主な著書に『信州まちなみスタディーズ〈佐久穂〉』（編著，2013年，信濃毎日新聞社)，『信州まちなみス夕 ディーズ II〈小諸〉』(編著, 2015 年, 信濃毎日新聞社).

ウェブサイト https://www.shinshu-u.ac.jp/faculty/econlaw/lab/mushasemi/ 